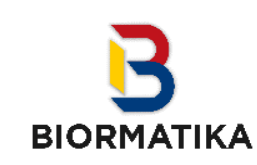

BIORMATIKA

\section{BIORMATIKA}

\author{
Jurnal Ilmiah Fakultas Keguruan dan Ilmu Pendidikan
}

http://ejournal.unsub.ac.id/index.php/FKIP/

\title{
The Influence Of English Song As Learning Materials Towards The Students' Pronunciation
}

\author{
Dewi Yulyanti ${ }^{1}$, Slamet Wahyudi Yulianto ${ }^{2}$, Muhammad Anjar Nugraha ${ }^{3}$ \\ Universitas Subang \\ dewiyulyanti66@gmail.com, slamet.wahyudi.y@gmail.com, anjarnugraha@ymail.com
}

\begin{tabular}{l} 
Info Artikel \\
\hline Sejarah Artikel: \\
Diterima Agustus 2019 \\
Disetujui September 2019 \\
Dipublikasikan September 2019
\end{tabular}

\section{Abstrak}

$\overline{\text { Penelitian ini menyelidiki apakah ada pengaruh lagu bahasa inggris }}$ terhadap pengucapan siswa. Penelitian ini menggunakan metode kuantitatif. Desain penelitian ini menggunakan kelas Eksperimen dan kelas Kontrol dari siswa kelas sebelas di SMAN 1 Ciasem. Peneliatian eksperimen dilakukan dalam empat pertemuan dengan mengamati proses belajar mengajar, tes, kuesioner dan wawancara dengan siswa. Hasil penelitian data kuantitatif, skor rata-rata pretest di kelas eksperimen adalah 14.44 dan standar deviasi adalah 1.647, sedangkan skor rata-rata di kelas kontrol adalah 14.58 . Dibandingkan dengan nilai rata-rata post-test kelas eksperimen adalah 82.98. Sementara, nilai rata-rata post-test di kelas kontrol adalah 60.56. Berdasarkan hasil skor siswa kelas eksperimen pada post-test lebih baik dengan rata-rata 82.89 dari skor post-test kelas kontrol rata-rata 60.56. Selain itu nilai dua sisi p adalah 0.000 yang lebih rendah dari 0.05 . Kesimpulannya, perhitungan paired t-test menunjukan ada perbedaan yang signifikan antara nilai pre-test dan post-test dari kelompok eksperimen. Analisis data kualitatif menunjukan bahwa menggunakan pengaruh lagu bahasa inggris melalui pelafalan siswa dengan mengamati proses belajar mengajar tes, kuesioner, dan wawancara, siswa lebih percaya diri dan tidak takut melakukan kesalahan saat pengucapan.

Kata Kunci: Teknik Lagu Bahasa Inggris, Pengaruh Pengucapan Siswa

\begin{abstract}
This research investigated whether or not there is the influence of English song towards the student's pronunciation. This research used a quantitative method. Research design is an experimental class and control class, two classes were selected from eleventh-grade students at SMAN 1 Ciasem Subang. The Quasi-Experimental Research was conducted in four meetings. The data were obtained by observing the
\end{abstract}


teaching and learning process, test, questionnaire, and interviewing the students. The research result of the analysis quantitative and qualitative data were as follows. The analysis of quantitative data, mean score of pre-test in the experimental class was 14.44. While the mean score in the control class was 14.58. Furthermore, the mean score of the post-test in the experimental class was 82.98. While the mean score post-test in the control class was 60.56. Based on the result, the experimental class students' score on post-test were better in which the mean $=82.89$ than their scores on pre-test the mean $=$ 60.56 . in addition, the two-tailed value of $p$ was 0.000 which was lower than 0.05 . in conclusion, the calculation of paired t-test showed that there was a significant difference between the pre-test and post-test scores of experimental group. The analysis of qualitative data show that used English song influence through students' pronunciation by observing the teaching and learning process, test, questionnaire, and interviewing the students. The students were more confident and were not afraid of making mistakes when pronunciation.

Keywords: English Song Technique, Influence of Students Pronunciation

\section{BACKGROUND}

Communication in second language (L2) is mainly suspended on correct pronunciation. It makes our speech understandable and enables us to be comprehensible interlocutors. Even with a rich lexicon in the second language and familiarity with the systems and structures of the L2, our messages cannot be expressed correctly without correct pronunciation, rhythm, and intonation (Varol, 2012). As mentioned by Harmer (in Gilakjani, 2016) that for all the students, being made aware of pronunciation issues will be of immense benefit not only to their own production but also to their own understanding of spoken English. The English language is spoken nowadays worldwide and is used in many workplaces. The students need to become proficient in English in general and improve their pronunciation in particular. In general, pronunciation includes the segmental and suprasegmental features of the language. Segments are the sounds of the vowels and consonants known as phonemes. The suprasegmental aspects focus on intonation, stress, and timing. In most of the Indonesian school, there are a lot of people with a strong desire to learn and speak English with correct pronunciation. However, there are many obstacles that hinder them to speak with good English pronunciation. The students face problems in the pronunciation of sounds which the students are not familiar with e.g. $/ \mathrm{v} /, / \mathrm{p} /, / \mathrm{g} /$ (Carter \& Nunan, 2001). Pronouncing certain consonant sounds incorrect, if people are misunderstanding, it could very well be due to confusing what we call "voiced" and "unvoiced" sounds. Sounds $/ \mathrm{p} /$ for $/ \mathrm{b} /$ or $/ \mathrm{H}$ for $\mathrm{H} / \mathrm{are}$ so easily confused because their only difference is whether or not you use your voice to produce them. Generally, the problem with teaching English as a foreign language in English is the difficulty experienced by the students with the consonant sounds that do not appear in the target language, such as the sound of thy and similar sounds like $/ \mathrm{b} /$ and $/ \mathrm{p} /$. The problem in learning English still exists at school. The special problem of the students learning a new set of language is against the background of their different native language habits. O'Connor (in Hassan, 2014) noted that the errors of pronunciation 
that learners of English from different language backgrounds make are systematic and not accidental. Consequently, teachers need to have a very good knowledge of what pronunciation entails so that they can help their students with their pronunciation problems. Learning English through song can be effective to help pronunciation since the students can immediately get the knowledge on how to pronounce the word from the song they hear. When students learn in an enjoyable situation, they commonly understand the lesson easily. To make a good shave or create interaction among the students in pronunciation class, teachers should apply some media, such as using games, songs, short stories, etc. These are all types of things which are ranged from simple to difficult, which help the students practice English while keeping the class alive and interesting (Finocchiaro in Fitri, 2016). According to the previous arguments, this research is conducted to find out whether there is a significant effect of listening to English songs towards students' pronunciation. The research takes place at SMAN 1 Ciasem Subang in 2019/2020 academic year. The data used in this research are collected using classroom observation, test, questionnaire, and interview.

\section{RESEARCH METHODOLOGY}

This research was conducted at SMAN 1 Ciasem Subang. It is located at Jl. Margasari 2 Sukamandi Ciasem, Sukamandijaya, Ciasem district, Subang regency, West Java. Hence, this research was conducted on July, $22^{\text {nd }}$ until $9^{\text {th }}$ August 2019 by administering quantitative and qualitative data to the sample of the research which are the first semester students of eleventh grade in SMAN 1 Ciasem Subang. The experimental class and control class was done as the method of conducting this research. In doing this research, the writer obtained data used classroom observation, test, questioner, and interview. The writer also used audiotape recording to record the data obtained because by audio tape recording technique an accurate and detailed data is needed to gain the data of the students' achievement in pronouncing English words. Stringer (in Thiel, 2014) asserts that the use of a tape recorder has the advantage of allowing the writer to record accounts that were both detailed and accurate.

At the beginning, the writer chooses the participant observation. The writer posing a genuine member of the group and overt was where the writer reveals his or her true identity and purpose to the group and asked permission to observe. Observational research consists of systematic observation. How the students' motivation, the students' response, participation, collaboration with others, and interest during the learning process. The word systematic implies a sensible and replicable procedure for collecting data Sherman (in Erdle, 1985). Hereinafter, for the purpose of checking as well as preventing misunderstanding the data from observations, classroom activities had proofed by English teacher in SMAN 1 Ciasem Subang. In a pre-test / post-test design, the same participants were measured on the variables of interest at multiple points in time. A test can be defined as a systematic procedure for observing one's behavior and describing it with the aid of numerical devices or category system Syakur (in Krisetyawati, 2010). A test of pronunciation may consist of the components such as vowels, consonants, intonation, word stress, and rhythm. The scoring rubric of this research is a range or a continuum scale over.

In conducting this research, the writer administered close-ended. These closed-ended questions, Likert scale multiple-choice question, typically were 5 pointer or above scale questions, Strongly Disagree $=1$, Disagree $=2$, Neutral $=3$, Agree $=4$, Strongly Agree $=5$, where the respondent was required to complete the questionnaire that needs them to indicate the extent to which they agree or disagree in experimental and control class. Sincero (2012) mentioned that the questions are the primary tools in collecting necessary information from the respondents of a survey. By making the right choices on the type of survey questions, will be able to 
extract only data that were related to the purpose or goal of the survey. Interviews explore the thinking, assumption, emotions, attitudes, perceptions which may be influencing the observed behavior of those involved in some way in the change in learning and teaching (L\&T) being evaluated, Cohen et al (2000). In this research towards structured interview questions with four students who have been interviewed, they were two more capable students and two less capable students in the experimental and control class. They shared their opinions in learning (i.e speaking) English, and their willingness to participate in different activities is observed. Follow-up interviews were conducted for collecting further information about the effectiveness of using songs with respect to the question.

\section{RESULT OF THE RESEARCH}

The improvement of students' pronunciation can be seen from the paired sample tests was represented. It can be seen from the average pre-test score (82.89) and the average of post-test (60.56) it is increased 22.33 point, which is means that the style of English song has an influence on student's pronunciation. Comparing the finding of my research with the relevant research reports had been conducted before. According to Fitri (2015) with the title Improving Students' Pronunciation by Using English Songs for fourth-semester Students of English Education program Batanghari University concluded from the post-test that there is statistical difference in the mean between experimental class and control class. The mean score of the experimental class is 91.78 and the mean score of the control class is 84.64. it means that the mean score of the experimental class is higher than the control class. Furthermore, based on observation, questionnaire, and interview about the influence of English song through students' pronunciation, the data presented students more active and enthusiastic in learning process by using English song. Comparing the finding of my research with the relevant research reports had been conducted before. According to Mulatsih (2015) found that the use of English Song is able to Increase the Pronunciation in Indonesian Students' of Unswagati Cirebon. The students were more interested in learning pronunciation using English songs. Because they got something new and enjoyable during their studies. They did not feel nervous and bored.

\section{CONCLUSION}

According to the findings and the conclusions of the research, a conclusion can be drawn as follows: Style English song, one of alternative material in students' pronunciation, is effective to influence the students' ability in pronunciation. The experimental research shows that the influence 0n students' pronunciation of the experimental class is statistically significant than the influence in the control class $(.000<0.05)$. Moreover, based on qualitative data by observation, questionnaire, and interview students practice more in order to make their pronunciation, especially in pronouncing the English words. More students participate actively and enjoyable with the materials in the learning process, and students feel that English songs should also solve the students' problem in learning pronunciation.

\section{REFFERENCES}

Carter, R. and Nunan, D. (Eds). (2001). The Cambridge Guide to teach English to Speakers of other Languages. Cambridge University Press. 294 pp.

Erdle, S. (1985) Personality, Classroom Behavior, and Student Ratings of College Teaching Effectiveness: A Path Analysis. Journal of Educational Psychology, Vol. 77, No. 4,394-407.

Fitri, N. (2015). Improving Students' Pronunciation By Using English Songs. Jurnal Ilmiah DIKDAYA.

Gilakjani, A. (2016). English
Pronunciation Instruction: A
Literature Review. International


Journal of Research in English Education. Online Published: November 18, 2016.

Hasan, E. (2014). Pronunciation Problems: A Case Study of English Language Students. English Language and Literature Studies; Vol. 4, No. 4; ISSN 1925-4768.

Krisetyawati, B. (2010). An Error Analysis on the TRANSLATION of English Noun Phrases into Indonesian. Surakarta : Sebelas Maret University.

Multasih, D. (2015). Pronunciation Ability By Using English Song In Indonesian Student Of Unswagati Cirebon. Journal of English Language and Learning, Vol. 2 No. 2, Mei 2015 ISSN : 2354-7340.

Sincero, S. (2012). Surveys and Questionnaires - Guide. Retrieved Nov 27, 2018 from Explorable.com:https://explorable. com/surveys-and-questionnaires.

Thiel, S. (2014). Research Methods in Public Administration and Public Management An Intoduction. Dutch : Coutinho Publisher

Varol, M. (2012). The influence of Turkish sound system on English pronounciation. Electronic Theses, Treatises and Dissertations. Paper 5451. 